\title{
Production of Metallic Titanium by Electrowinning in Molten Salts of Titanium Oxycarbide Anode ${ }^{\dagger}$
}

\author{
Btissem Malek ${ }^{1}$, Jerome Serp ${ }^{1, *}$, Franck Doreau ${ }^{1} \mathbb{D}$, Manuel Miguirditchian ${ }^{1}$, Marion Vandenhende ${ }^{2}$, \\ Nicolas Pradeilles ${ }^{2}$,, Yann Lepetitcorps ${ }^{3}$ and Alexandre Maitre ${ }^{2}$
}

1 CEA, DES, ISEC, DMRC, University of Montpellier, Marcoule, 30207 Bagnols sur Ceze, France; btissem.malek@cea.fr (B.M.); franck.doreau@cea.fr (F.D.); manuel.miguirditchian@cea.fr (M.M.)

2 IRCER, Institute of Research for Ceramics, University of Limoges, 87068 Limoges, France; marion.vandenhende@unilim.fr (M.V.); nicolas.pradeilles@unilim.fr (N.P.); alexandre.maitre@unilim.fr (A.M.)

3 LCTS, Laboratory of Thermo Structural Composites, University of Bordeaux, 33000 Bordeaux, France; LEPETITCORPS@lcts.u-bordeaux.fr

* Correspondence: Jerome.serp@cea.fr; Tel.: +33-4-66-33-94-72

+ Presented at International Conference on Raw Materials and Circular Economy, Athens, Greece, 5-9 September 2021.

check for updates

Citation: Malek, B.; Serp, J.; Doreau, F; Miguirditchian, M.; Vandenhende, M.; Pradeilles, N.; Lepetitcorps, Y.; Maitre, A. Production of Metallic Titanium by Electrowinning in Molten Salts of Titanium Oxycarbide Anode. Mater. Proc. 2021, 5, 63. https://doi.org/10.3390/ materproc2021005063

Academic Editor: Anthimos Xenidis

Published: 7 December 2021

Publisher's Note: MDPI stays neutral with regard to jurisdictional claims in published maps and institutional affiliations.

Copyright: (C) 2021 by the authors Licensee MDPI, Basel, Switzerland. This article is an open access article distributed under the terms and conditions of the Creative Commons Attribution (CC BY) license (https:/ / creativecommons.org/licenses/by/ $4.0 /)$.

\begin{abstract}
The electrochemical behavior of $\mathrm{Ti}^{3+}$ in $\mathrm{LiCl}-\mathrm{LiF}-\mathrm{TiF}_{3}$ salt was investigated by cyclic and square wave voltammetries at $853 \mathrm{~K}$. Both methods confirm the presence of a single reduction wave of $\mathrm{Ti}^{3+}$ ions to metal, at a potential of $-2.3 \mathrm{~V} \mathrm{vs.} \mathrm{Cl}_{2} / \mathrm{Cl}^{-}$. The closeness of the potentials of $\mathrm{TiC}_{\mathrm{x}} \mathrm{O}_{\mathrm{y}}$ dissolution and $\mathrm{Ti}^{3+} / \mathrm{Ti}^{4+}$ wave is an issue during the electrorefining of the anode. A low current density has to be applied to stay within the titanium oxycarbide dissolution and avoid the formation of $\mathrm{Ti}^{4+}$. The titanium deposition was studied by electrorefining of a titanium metal plate in $\mathrm{LiCl}_{-} \mathrm{LiF}_{-} \mathrm{TiF}_{3}(0.62 \mathrm{~mol} / \mathrm{kg})$. The cathodic deposit analysis by XRD and SEM confirms the formation of titanium metal with an average grain size of $150 \mu \mathrm{m}$. The faradic deposition yields are above $85 \%$ and constant between 60 and $160 \mathrm{~mA} / \mathrm{cm}^{2}$.
\end{abstract}

Keywords: Chinuka process; titanium electrowinning; electrochemical deposition; fluoride chloride melt; titanium oxycarbide

\section{Introduction}

Titanium, the ninth most abundant element in the earth's crust, has many attractive properties such as lightweight, high specific strength, corrosion and oxidation resistance at elevated temperatures. It can be used as high-temperature structural material widely used in aerospace, petrochemical, automobile, and metallurgical industries [1].

This material is produced by the Kroll process since 1940s. The process allows the conversion of $\mathrm{TiO}_{2}$ into $\mathrm{Ti}$ metal. $\mathrm{TiO}_{2}$ is transformed into $\mathrm{TiCl}_{4}$ by the action of chlorine gas at high temperature (carbochlorination). $\mathrm{TiCl}_{4}$ is then converted to metal by reduction with metallic magnesium. This highly exothermic reaction leads to the formation of liquid $\mathrm{MgCl}_{2}$ and a metallic titanium sponge [2], according to the following reactions:

$$
\begin{aligned}
\mathrm{TiO}_{2}+\mathrm{Cl}_{2(\mathrm{~g})}+\mathrm{C} & \rightarrow \mathrm{TiCl}_{4(\mathrm{~g})}+\mathrm{CO}_{2(\mathrm{~g})} \\
\mathrm{TiCl}_{4(\mathrm{~g})}+2 \mathrm{Mg}_{(\text {liq })} & \rightarrow 2 \mathrm{MgCl}_{2(\mathrm{liq})}+\mathrm{Ti}_{(\mathrm{s})}
\end{aligned}
$$

Titanium sponge is finally obtained after a $\mathrm{MgCl}_{2}$ distillation step.

This high-cost batch [3] process requires optimal operation and wastes minimization, a chlorine gas production unit, and a magnesium metal production workshop by electrolysis of $\mathrm{MgCl}_{2}$ (resulting from the reduction reaction of $\mathrm{TiCl}_{4}$ ).

As an alternative method of the Kroll process, molten salt electrolysis has been frequently proposed. 
The first difficulty in the electrochemistry of titanium lies in controlling its oxidation state in the molten salt solution [4].

This problem is especially true in molten chloride, for which $\mathrm{Ti}^{0}, \mathrm{Ti}^{2+}, \mathrm{Ti}^{3+}, \mathrm{Ti}^{4+}$ can exist in the salt. This particularity is explained by the existence of several equilibria that lead to losses in faradic efficiency [4]:

$$
\begin{aligned}
& 3 \mathrm{TiCl}_{4}+\mathrm{Ti}^{0} \rightarrow 4 \mathrm{TiCl}_{3} \\
& 2 \mathrm{TiCl}_{3}+\mathrm{Ti}^{0} \rightarrow 3 \mathrm{TiCl}_{2}
\end{aligned}
$$

Since the 2000s, the FFC (Fray, Farthing, and Chen) [5] and OS (Ono and Suzuki) [6] processes have opened a new route through the electrolytic reduction of $\mathrm{TiO}_{2}$ into $\mathrm{Ti}$ in molten chlorides. The metal production at the cathode involves a reducing agent formed in situ by reduction of the molten salt solvent (e.g., calcium). These processes overcome the difficulty of multiple oxidation states of titanium in solution since titanium is present in the processes as porous $\mathrm{TiO}_{2}$ pellets reduced at the cathode. The $\mathrm{TiO}_{2}$ electroreduction leads to the formation of oxide ions that can be converted at a graphite anode into $\mathrm{CO} / \mathrm{CO}_{2}$ or $\mathrm{O}_{2}$ with a non-consumable anode. However, the anodic reaction between graphite and oxides ions forms electro-reducible carbonates, which cause faradic yield losses and can contaminate the cathode deposit. Platinum, gold, $\mathrm{SnO}_{2}$ anodes cannot be considered as non-consumable anodes as degradation products have been frequently reported [7]. These processes therefore still require further developments to find a suitable anode, and the titanium product is often contaminated with carbon and residual oxygen [8].

The process studied in this work is the Chinuka process (also studied in the literature under the names MER and USTB). In this route, titanium oxycarbide $\left(\mathrm{TiC}_{\mathrm{x}} \mathrm{O}_{\mathrm{y}}\right)$ is used as the anode in molten chlorides. When the right potential is applied, $\mathrm{CO}$ is released at the anode together with $\mathrm{Ti}^{3+}$ and $/$ or $\mathrm{Ti}^{2+}$ ions that are dissolved into the molten salt and transferred to the cathode for electrodeposition $[9,10]$.

In this work, the melt composition has been optimized to minimize the $\mathrm{Ti}^{2+}$ concentration in the salt phase. The solution adopted to solve the problem of multiple oxidation states consists in adjusting the degree of complexation of titanium ions in solution, either by modifying the so-called chloroacidity of the medium or by adding fluoride ions.

Numerous studies dealt with the electrochemical behavior of titanium in chloride medium. They allowed highlighting the presence of $\mathrm{Ti}^{3+}$ and $\mathrm{Ti}^{2+}$ and identifying a multistep reduction mechanism [11] according to the reactions:

$$
\mathrm{Ti}^{4+}+\mathrm{e}^{-} \rightarrow \mathrm{Ti}^{3+}, \mathrm{Ti}^{3+}+\mathrm{e}^{-} \rightarrow \mathrm{Ti}^{2+} \text { and } \mathrm{Ti}^{2+}+2 \mathrm{e}^{-} \rightarrow \mathrm{Ti}^{0}
$$

The existence of these multiple oxidation states in solution involves disproportionation reactions (3) and (4), which can decrease the faradic efficiencies [12,13] and generate sludge formation [14].

In chloro-fluoride salts, studies [15] have shown that increasing the concentration of fluoride ions in the molten salt leads removing the $\mathrm{Ti}^{2+} / \mathrm{Ti}^{3+}$ electronic transition [16].

The overall idea of this work is to use a high concentration of fluoride ions (hence the use of a chloro-fluoride salt) in the Chinuka process.

To study the reduction mechanism of titanium ions, the choice was made on a salt rich in fluoride: $\mathrm{LiCl}-\mathrm{LiF}(70-30 \mathrm{~mol} \%)$.

\section{Experimental}

\subsection{Preparation of Titanium Oxycarbide Anode}

The carboreduction route has been used to synthesize titanium oxycarbide anode from a mixture of titanium dioxide (Alfa Aesar, purity 99.6\%) and black carbon (Alfa Aesar, 
purity $99.9 \%$ ). The raw powders were mixed in a mortar according to the stoichiometric proportion given by the following equation:

$$
\mathrm{TiO}_{2}+2 \mathrm{C} \rightarrow \mathrm{TiC}_{0.5} \mathrm{O}_{0.5}+\frac{3}{2} \mathrm{CO}
$$

The mixtures obtained were then heat treated under flowing argon $\left(16 \mathrm{~L} \cdot \mathrm{h}^{-1}\right)$ at $1773 \mathrm{~K}$ $\left(1500{ }^{\circ} \mathrm{C}\right)$. This treatment lasted four hours followed by annealing at the same conditions as the first carboreduction in order to reach the desired stoichiometry of the titanium oxycarbide phase: $\mathrm{Ti}_{2} \mathrm{CO}$ [17]. Finally, the titanium oxycarbide powder was sintered by SPS (Spark Plasma Sintering) [18] at $100 \mathrm{MPa}$ for $5 \mathrm{~min}$ at $1923 \mathrm{~K}\left(1650^{\circ} \mathrm{C}\right)$ (Figure 1).

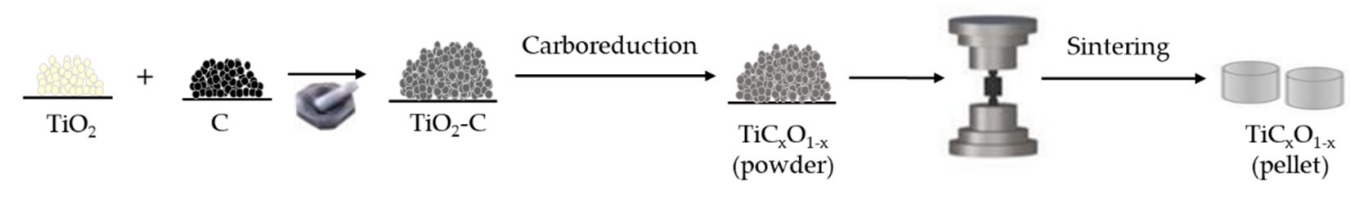

Figure 1. The diagram summarizes the process of synthesis and shaping of the titanium oxycarbide anode.

\subsection{Electrolysis Process}

The electrolyte consisted of a eutectic LiCl-LiF melt (70-30 mol\%, 99-99.98\%). It was dried at $423 \mathrm{~K}$ for a minimum of $24 \mathrm{~h}$. Experiments were carried out in an argon glovebox. The salt was introduced in a glassy carbon crucible. Temperature was progressively risen to the working temperature (853-953 K) under argon atmosphere.

A concentration of $0.62 \mathrm{~mol} / \mathrm{kg}$ of potassium hexafluorotitanate solute $\left(\mathrm{K}_{2}^{+}, \mathrm{Ti}^{4+}, \mathrm{F}_{6}^{-}\right)$ was added to the electrolyte and reduced to $\mathrm{Ti}^{3+}$ with a pure titanium plate. The working temperature was measured by a thermocouple protected by a glassy carbon tube and inserted into the melt.

\subsection{Electrodes}

To investigate the electrochemical behavior of titanium ions, a three-electrode setup was used. A tungsten wire with a diameter of $0.5 \mathrm{~mm}$ served as the working electrode, a molybdenum spiral was used as the counter electrode, and a molybdenum wire with a diameter of $1 \mathrm{~mm}$ was utilized as the quasi-reference electrode. All RE potentials were referred to $\mathrm{Cl}_{2} / \mathrm{Cl}^{-}$redox couple. The conversion was obtained by graphical estimation of the potential at zero current in the linear variation region during the positive scan of voltammograms, as shown in reference [19].

For the electrorefining experiments, a titanium plate is used as an anode to study titanium electrodeposition. The cathode is a $5 \mathrm{~mm}$ diameter molybdenum rod.

\subsection{Electrochemical Techniques Used}

Electrochemical techniques, including cyclic voltammetry and square wave voltammetry, were used to study the mechanism of titanium ions reduction.

\subsection{Materials Characterization}

After electrolysis, the cathode was removed from the bath and washed in an ultrasonic tank containing a water solution to remove all residual salt. Titanium deposits were characterized using X-ray diffraction (XRD). The scanning electron microscopy (SEM) was carried out to observe the microstructure of titanium deposits.

\section{Results and Discussion}

\subsection{Electrochemical Behavior of Titanium Ions}

In order to be representative of an electrolyzer (reducing conditions), a titanium plate was dipped permanently into the molten salt. 


\subsubsection{Cyclic Voltammetry (CV)}

The chloro-fluoride salt $\mathrm{LiCl}-\mathrm{LiF}(70-30 \mathrm{~mol} \%)$ has an $\mathrm{F} / \mathrm{Cl}$ ratio of 0.43 . After adding $\mathrm{K}_{2} \mathrm{TiF}_{6}$, the $\mathrm{F} / \mathrm{Cl}$ ratio becomes 0.58 and the $\mathrm{F} / \mathrm{Ti}$ ratio is 23 .

The cyclic voltammograms obtained in $\mathrm{LiCl}-\mathrm{LiF}$ containing dissolved titanium as well as the anodic polarization curve of titanium oxycarbide in $\mathrm{LiCl}-\mathrm{LiF}$ at $853 \mathrm{~K}\left(580^{\circ} \mathrm{C}\right)$ are shown in Figure 2. The scan rate was $100 \mathrm{mV} / \mathrm{s}$.

After the addition of $\mathrm{K}_{2} \mathrm{TiF}_{6}$ and titanium plate in pure $\mathrm{LiCl}-\mathrm{LiF}$ molten salt, two oxidation peaks associated with two reduction peaks appeared. The first one at around $-0.5 \mathrm{~V}$ vs. $\mathrm{Cl}_{2} / \mathrm{Cl}^{-}$corresponds to the $\mathrm{Ti}^{3+} / \mathrm{Ti}^{4+}$ soluble-soluble redox couple. The second one at about $-2.3 \mathrm{~V}$ vs. $\mathrm{Cl}_{2} / \mathrm{Cl}^{-}$is attributed to the reduction of $\mathrm{Ti}^{3+}$ in Ti metal in a single step associated to its sharp stripping peak:

$$
\mathrm{Ti}^{3+}+3 \mathrm{e}^{-} \rightarrow \mathrm{Ti}^{0}
$$

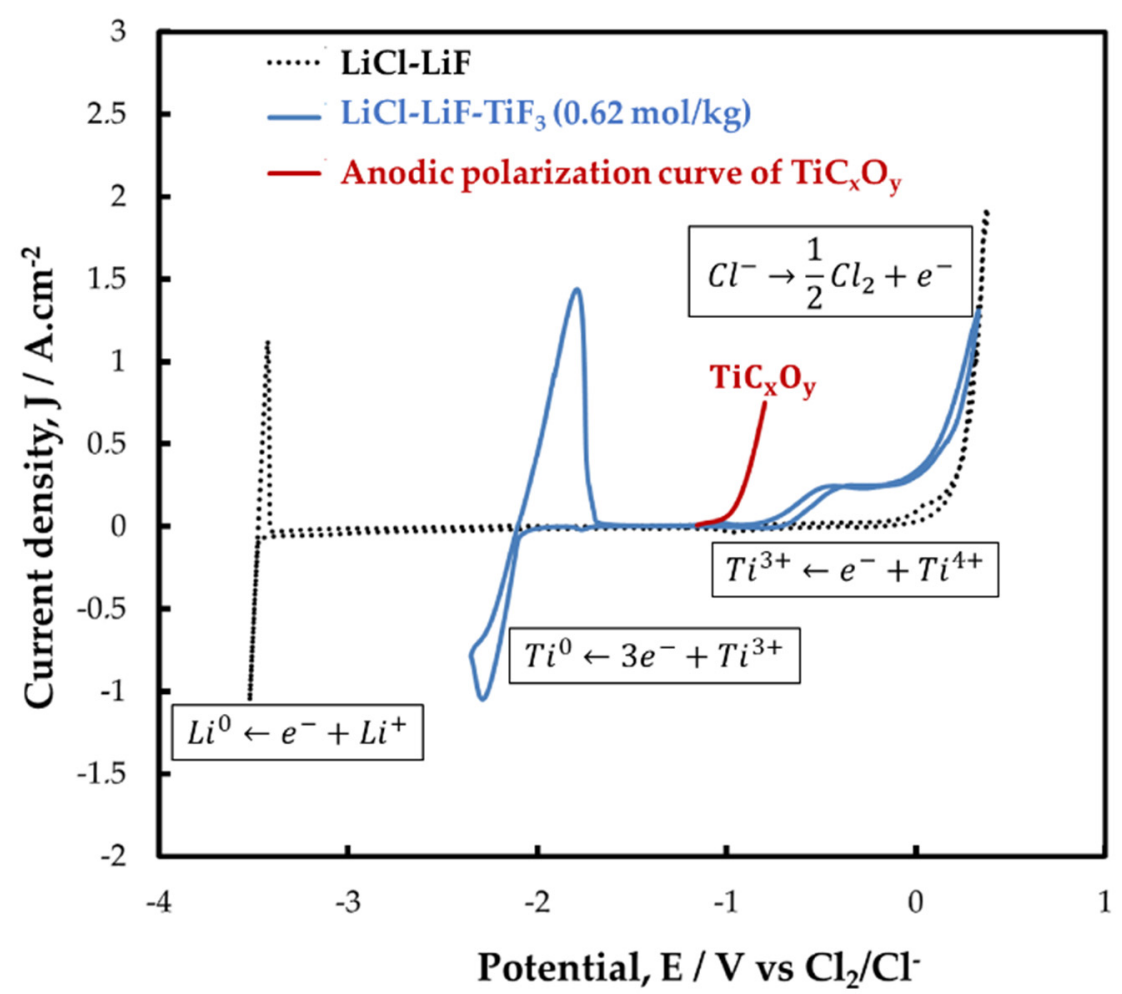

Figure 2. Cyclic voltammograms on a tungsten electrode $\left(\mathrm{S}=0.2 \mathrm{~cm}^{2}\right)$ in $\mathrm{LiCl}-\mathrm{LiF}$ (black) and LiCl$\mathrm{LiF}_{-\mathrm{TiF}}(0.62 \mathrm{~mol} / \mathrm{kg})$ (blue) and anodic polarization curve of $\mathrm{TiC}_{\mathrm{x}} \mathrm{O}_{\mathrm{y}}(\mathrm{Red})$, at $853 \mathrm{~K}$ with the scan rate of $100 \mathrm{mV} \cdot \mathrm{s}^{-1}$.

\subsubsection{Square Wave Voltammetry (SWV)}

SWV was used to estimate the number of electrons exchanged on the $-2.3 \mathrm{~V}$ vs. $\mathrm{Cl}_{2} / \mathrm{Cl}^{-}$system. Figure 3 shows that the peak current density is increasing with the increase of frequency.

As shown in the inserted figure (in Figure 3), the differential current density ( $\delta \mathrm{J}$ $\left.\left(A \cdot \mathrm{cm}^{-2}\right)\right)$ is proportional to the square root of the frequency $(\mathrm{f}(\mathrm{Hz}))$. Square wave voltammetry allows thus, by measuring the width at half-height of the peak $\left(\mathrm{W}_{1 / 2}\right)$, to calculate the number of electrons exchanged, using the following equation [20]:

$$
\mathrm{W}_{\frac{1}{2}}=3.52 \frac{\mathrm{RT}}{\mathrm{nF}}
$$


where, $\mathrm{R}$ is the ideal gas constant $\left(8.314 \mathrm{JK}^{-1} \cdot \mathrm{mol}^{-1}\right), \mathrm{T}$ is the temperature $(\mathrm{K}), \mathrm{n}$ is the exchanging electron number, and $\mathrm{F}$ is the Faraday constant $\left(96,500 \mathrm{C} \cdot \mathrm{mol}^{-1}\right)$.

To overcome the disturbance caused by nucleation phenomenon, the measurement of the half-width at half-height $0.5 \mathrm{~W}_{1 / 2}$ was performed on the second half of the metal reduction signal, as shown in Figure 3.

Using Equation (8), the average number of electrons in the frequency range of 9 to $49 \mathrm{~Hz}$ varies between 3.07 and 3.17. This confirms that the reduction peak at $-2.3 \mathrm{~V}$ vs. $\mathrm{Cl}_{2} / \mathrm{Cl}^{-}$can be attributed to the reduction of $\mathrm{Ti}^{3+}$ into metallic titanium.

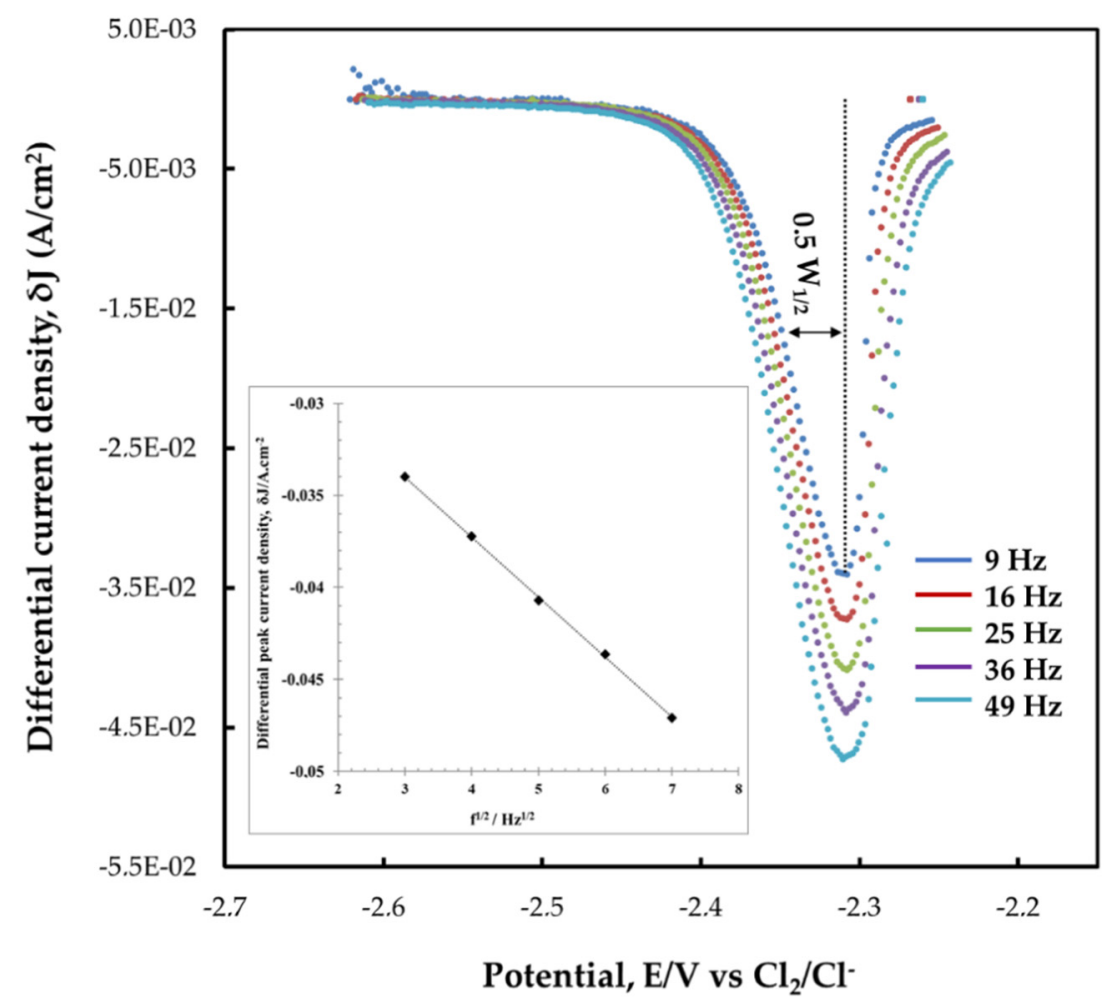

Figure 3. Square wave voltammograms on a tungsten electrode $\left(0.12 \mathrm{~cm}^{2}\right)$ in $\mathrm{LiCl}-\mathrm{LiF}-\mathrm{TiF}_{3}(7.25 \times$ $10^{-2} \mathrm{~mol} \cdot \mathrm{kg}^{-1}$ ) at $853 \mathrm{~K}$ under various frequencies. Insert linear relationship of $\mathrm{Ti}^{3+}$ peak current density versus square root of frequency.

\subsubsection{Titanium Oxycarbide Anodic Dissolution}

The red curve in Figure 2 shows the anodic polarization curve of $\mathrm{TiC}_{\mathrm{x}} \mathrm{O}_{\mathrm{y}}$. As the potential was raised beyond $-1 \mathrm{~V}$ vs. $\mathrm{Cl}_{2} / \mathrm{Cl}^{-}$, the current density increased rapidly, attributed to the occurrence of electrochemical dissolution of $\mathrm{TiC}_{\mathrm{x}} \mathrm{O}_{\mathrm{y}}$ solid solution.

The dissolution potential of titanium oxycarbide is close to the potential of $\mathrm{Ti}^{3+} / \mathrm{Ti}^{4+}$ couple, i.e., $-0.5 \mathrm{~V}$. During the electrorefining of $\mathrm{TiC}_{0.5} \mathrm{O}_{0.5}$ low current densities will have to be applied in order to avoid the formation of $\mathrm{Ti}^{4+}$ and the problem of disproportionation reaction between $\mathrm{Ti}^{0}$ and $\mathrm{Ti}^{4+}$ that would decrease the faradic yield.

\subsection{Electrodeposition of Titanium}

Electrorefining of titanium was performed at high $\mathrm{Ti}^{3+}(0.62 \mathrm{~mol} / \mathrm{kg})$ concentration in $\mathrm{LiCl}-\mathrm{LiF}$ at different temperatures. The elaboration of metallic titanium deposits by electrorefining in a molten $\mathrm{LiCl}-\mathrm{LiF}$ salt is realized in the first step by anodic dissolution of a titanium plate in order to optimize the electrochemical parameters.

Electrolysis was performed at a current density of $60 \mathrm{~mA} \cdot \mathrm{cm}^{-2}$ for $2 \mathrm{~h}$ and $30 \mathrm{~min}$. After electorefining tests, the cathode was coated with a mixture of titanium deposit and salt (see picture in Figure 4). The deposit was washed, dried, and weighed. The metal after cleaning is easier to obtain in a powder form than a dendritic one. Figure 4 shows 
XRD pattern of cathode deposit. It confirms that the obtained cathodic deposit is metallic titanium.

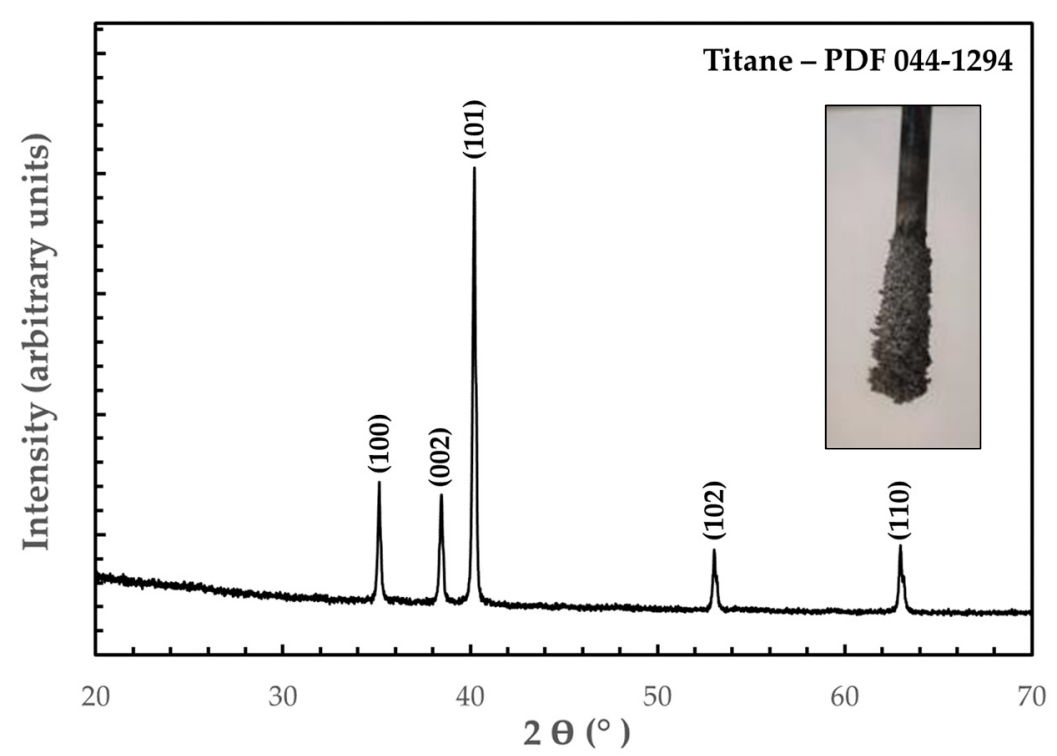

Figure 4. X-ray diffraction of titanium metal deposited on the cathode under the current density of $60 \mathrm{~mA} \cdot \mathrm{cm}^{-2}$ in LiCl-LiF-TiF $3(0.62 \mathrm{~mol} / \mathrm{kg})$ at $853 \mathrm{~K}\left(580^{\circ} \mathrm{C}\right)$. Insert image of titanium deposit.

Figure 5 shows an SEM micrograph of a titanium deposit obtained through electrolysis, which exhibits a crystalline microstructure. The crystallites are approximately $150 \mu \mathrm{m}$, well above the limit where titanium is considered as pyrophoric (less than $5 \mu \mathrm{m}$ [21]).

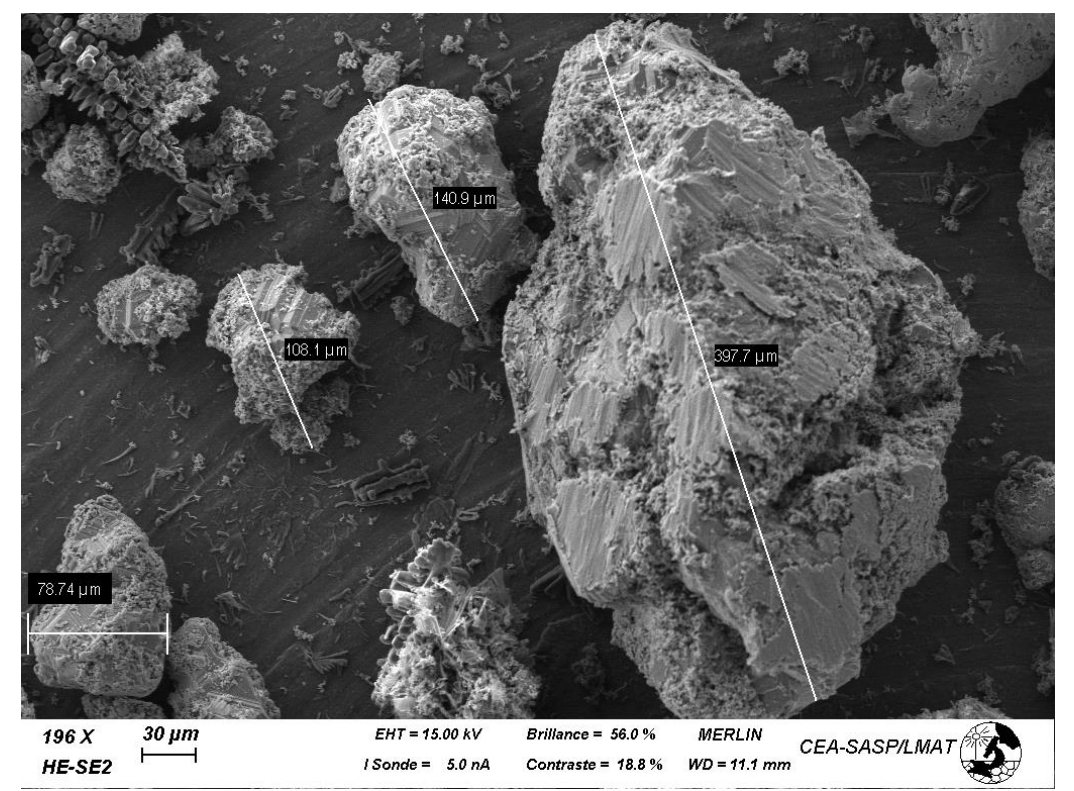

Figure 5. SEM micro-morphology of titanium metal deposit on the cathode under the current deposit of $60 \mathrm{~mA} \cdot \mathrm{cm}^{-2}$ in $\mathrm{LiCl}-\mathrm{LiF}-\mathrm{TiF}_{3}(0.62 \mathrm{~mol} / \mathrm{kg})$ at $853 \mathrm{~K}\left(580{ }^{\circ} \mathrm{C}\right)$.

The faradic yields obtained from the calculated theoretical mass and the experimental mass obtained by weighing the deposits are about $85 \%$.

The experiment was repeated at different current density over a range from 60 to $160 \mathrm{~mA} \cdot \mathrm{cm}^{-2}$, and temperature from $853 \mathrm{~K}\left(580^{\circ} \mathrm{C}\right)$ to $953 \mathrm{~K}\left(700^{\circ} \mathrm{C}\right)$. Faradic efficiencies were stable within this current range and slightly higher at $953 \mathrm{~K}$. 


\section{Conclusions}

The study of the reduction mechanism of titanium ions in LiCl-LiF chloro-fluoride salt showed that $\mathrm{Ti}^{3+}$ is reduced to Ti metal in a single step involving three electrons.

The dissolution potential of $\mathrm{TiC}_{\mathrm{x}} \mathrm{O}_{\mathrm{y}}$ is close to the $\mathrm{Ti}^{3+} / \mathrm{Ti}^{4+}$ wave. In electrorefining of titanium oxycarbide, it is important to apply low current density to avoid the formation of $\mathrm{Ti}^{4+}$.

The faradic current efficiencies obtained after electrorefining a titanium plate between 60 and $160 \mathrm{~mA} \cdot \mathrm{cm}^{-2}$ are high, around $85 \%$ at $853 \mathrm{~K}$ and $90 \%$ at $953 \mathrm{~K}$.

XRD and SEM characterization of the metal deposit shows the formation of metallic titanium with a grain size of around $150 \mu \mathrm{m}$.

Future work will be dedicated to the electrorefining of titanium oxycarbide in the experimental conditions optimized in this work.

\section{References}

1. Yves COMBRES. Propriétés du Titane et de ses Alliages. Techniques de l'ingénieur, Réf.: M4780 V1. 10 March 2010. Available online: https:/ / www.techniques-ingenieur.fr/res/pdf/encyclopedia/42357210-m4780.pdf (accessed on 4 December 2021).

2. Kroll, W.; Fink, C.G.; Summers, D.B. The Production of Ductile Titanium. Trans. Electrochem. Soc. 1940, 78, 35-649. [CrossRef]

3. van Vuuren, D.S. A critical evaluation of processes to produce primary titanium. J. S. Afr. Inst. Min. Metal. 2009, 109, 455-461.

4. Marco, V.; Ginatta, G.T.T. Titanium Electrowinning. In Proceedings of the International Symposium on Ionic Liquids in Honour of Marcelle Gaune-Escard. Carry le Rouet, France, 27-28 June 2003; pp. 3-4.

5. Chen, G.; Fray, D.J.; Farthing, T.W. Direct electrochemical reduction of titanium dioxide to titanium in molten calcium chloride. Nat. Cell Biol. 2000, 407, 361-364. [CrossRef] [PubMed]

6. Ono, K.; Suzuki, R.O. A new concept for producing Ti sponge: Calciothermic reduction. J. Miner. Metals Mater. Soc. 2002, 54, 59-61. [CrossRef]

7. Mohandas, K.S. Direct electrochemical conversion of metal oxides to metal by molten salt electrolysis: A review. Miner. Process. Extr. Met. 2013, 122, 195-212. [CrossRef]

8. Bertolini, M.; Shaw, L.; England, L.; Rao, K.; Deane, J.; Collins, J. The FFC Cambridge Process for Production of Low Cost Titanium and Titanium Powders. Key Eng. Mater. 2010, 436, 75-83. [CrossRef]

9. Fray, D.J.; Jiao, S. Treatment of Titanium Ores. Chinuka Limited. GB 2472496. 28 July 2010. Available online: https:/ /www. mysciencework.com/patent/download/treatment-titanium-ores-EP2462251B1/EP2462251B1 (accessed on 4 December 2021).

10. Ning, X.; Xiao, J.; Jiao, S.; Zhu, H. Anodic dissolution of titanium oxycarbide $\mathrm{TiC}_{\mathrm{x}} \mathrm{O}_{1-\mathrm{x}}$ with different $\mathrm{O} / \mathrm{C}$ ratio. J. Electrochem. Soc. 2019, 166, E22-E28. [CrossRef]

11. Popov, B.N.; Kimbl e, M.C.; White, R.E.; Wendt, H. Electrochemical behaviour of titanium(II) and titaniun(III) compounds in molten lithium chloride/potassium chloride eutectic melts. J. Appl. Electrochem. 1991, 21, 351-357. [CrossRef]

12. Zhu, H. Rare Earth Metal Production by Molten Salt Electrolysis. In Encyclopedia of Applied Electrochemistry; Springer: New York, NY, USA, 2014; pp. 1765-1772.

13. Head, R.B. Electrolytic Production of Sintered Titanium from Titanium Tetrachloride at a Contact Cathode. J. Electrochem. Soc. 1961, 108, 806. [CrossRef]

14. Haarberg, G.M.; Rolland, W.; Sterten, A.; Thonstad, J. Electrodeposition of titanium from chloride melts. J. Appl. Electrochem. 1993, 23, 217-224. [CrossRef]

15. Song, J.; Wang, Q.; Zhu, X.; Hou, J.; Jiao, S.; Zhu, H. The Influence of Fluoride Anion on the Equilibrium between Titanium Ions and Electrodeposition of Titanium in Molten Fluoride-Chloride Salt. Mater. Trans. 2014, 55, 1299-1303. [CrossRef]

16. Norikawa, Y.; Yasuda, K.; Nohira, T. Electrodeposition of Titanium in a Water-Soluble KF-KCl Molten Salt. Mater. Trans. 2017, 58 , 390-394. [CrossRef]

17. Réjasse, F. Study of the Reactivity of Group Ivb Metallic Dioxides in the Presence of Carbon by a (Micro)-Structural Approach: Application to the Thermodynamic Modelling of Ternary Phase Diag. Ph.D. Thesis, University of Limoges, Limoges, France, 2 December 2015; pp. 125-243.

18. Gendre, M.; Maître, A.; Trolliard, G. Synthesis of zirconium oxycarbide (ZrCxOy) powders: Influence of stoichiometry on densification kinetics during spark plasma sintering and on mechanical properties. J. Eur. Ceram. Soc. 2011, 31, 2377-2385. [CrossRef]

19. Geran, S.; Chamelot, P.; Serp, J.; Gibilaro, M.; Massot, L. Electrochemistry of Uranium in Molten LiCl-LiF; Elsevier: Amsterdam, The Netherlands, 23 April 2020.

20. Ramaley, L.; Krause, M.S. Theory of square wave voltammetry. Anal. Chem. 1969, 41, 1362-1365. [CrossRef]

21. Dring, K. Challenges and Opportunities in Titanium Metal Production, Is There Still Any Interest/Need to Replace Kroll Production? Norsk Titanium AS: Oslo, Norway; pp. 12-14. Available online: https:/ /www.okabe.iis.u-tokyo.ac.jp/workshop/090219_Workshop_ SanFrancisco_for_Okabe_lab_HP/parts/doc.C.pdf (accessed on 4 November 2021). 